EESTI NSV TEADUSTE AKADEEMIA TOIMETISED. XVII KÖIDE

KEEMIA * GEOLOOGIA. 1968, Nr. 2

ИЗВЕСТИЯ АКАДЕМИИ НАУК ЭСТОНСКОЙ ССР. ТОМ ХVII

ХИМИЯ * ГЕОЛОГИЯ. 1968, № 2

\title{
ИССЛЕДОВАНИЕ ТЕРМИЧЕСКОЙ ДЕСТРУКЦИИ ЭТИЛФЕНОЛОВ В ПРИСУТСТВИИ ВОДЯНОГО ПАРА
}

Одним из авторов настоящей статьи [1] было показано, что смола термическงй переработки горючего сланца содержит значительные количества фенольных соединений, относящихся в основном к двухъядерным, гетероциклическим и двухатомным фенолам, и сравнительно мало первых членов гомологического ряда оксибензола. Такой состав сланцевых фенолов тормозит широкое их применение в народном хозяйстве. Но так как ресурсы сланцевых фенолов при современном уровне переработки сланщев исчисляются десятками тысяч тонн в год, то они могли бы представить большой интерес для народного хозяйства. Поэтому необходимо было продолжигь исследования методов переработки фенолов, позволяющих получить из высших фенолов их простейшие представители.

Изучению термической и каталитической деструкции сланцевых фенолов посвлщено немало работ [2-6]. Установлено, что деструкция фенолов сопровождается значительным образованием продуктов конденсации, кокса и углеводородов и что выход низших фенолов незначительный. $\mathrm{K}$ сожалению, названные работы еще не позволяют голучить полное представление о механизме процесса термической деструкции и объяснить причины этих явлений. Поэтому многие авторы $\left[{ }^{7-10}\right]$ исследовали деструкцию индивидуальных фенолов, особенно крезолов, с целью выяснения характера и механизма процесса деструкции. В результате этих опытов выяснилось, что при деструкции крезолов образуются бензол, толуол и фенол. Термодинамические расчеты, проведенные Н. Груздевой $\left[{ }^{11}\right]$ и Елинеком $\left[{ }^{12}\right]$ показали, что среди многих реакций деструкции фенолов наиболее вероятна реакция, приводящая к образованию бензола, метана и воды. Исследованиями Б. В. Джонса и М. Б. Ньюворта $\left.{ }^{[13}\right]$ установлено, что при деструкции крезолов в атмосфере водяного пара образуется только незначительное количество кокса и продуктов уплотнения. Эти результаты подтвердились также при деструкции сланцевых фенолов [3,5].

Имеющиеся в литературе данные о деструкции фенолов в присутствии водяноro пара немногочисленны и не позволяют сделать выводы о характере основных продуктов реакции и о ее механизме. Как показали наши исследования по термической деструкции нафтолов в присутствии водяного пара [14], механизм главных направленнй деструкции в значительной степени зависит от строения исходного фенола. Поэтому дальнейшие детальные исследования деструкции индивидуальных фенолов вполне обоснованы и актуальны. В настоящей статье мы приводим результаты деструкции o- и $n$-этилфенолов в присутствии водяного пара при температурах $700-$ $750^{\circ} \mathrm{C}$.

\section{Экспериментальная часть}

При исследовании деструкции этилфенолов нами использовалась аппаратура, состоящая из наклонно установленной кварцевой трубки, обогреваемой двумя электропечами. К средней части кварцевой трубки 
Таблица 1

Состав продуктов, образовавшихся при деструкции $\sigma$ - и $n$-этилфенолов в присутствии водяного пара

\begin{tabular}{|c|c|c|c|c|}
\hline Показатели & \multicolumn{2}{|c|}{$o$-Этилфенол } & \multicolumn{2}{|c|}{ n-Этилфенол } \\
\hline $\begin{array}{l}\text { Tемпература реакции, }{ }^{\circ} \mathrm{C} \\
\text { Степень конверсии, \% }\end{array}$ & $\begin{array}{l}700 \\
23,6\end{array}$ & $\begin{array}{l}750 \\
52,6\end{array}$ & $\begin{array}{l}700 \\
11,2\end{array}$ & $\begin{array}{l}750 \\
31,8\end{array}$ \\
\hline \multirow{2}{*}{\multicolumn{5}{|c|}{$\begin{array}{l}\text { Выход продуктов деструкции в } \\
\text { процентах на исходный этил- } \\
\text { фенол: }\end{array}$}} \\
\hline жидкие продукты & 93,3 & 84,9 & & 89,0 \\
\hline газовые продукты & 4,0 & 11,5 & 2,0 & 7,7 \\
\hline кокс & 0,1 & 0,2 & 0,1 & 0,2 \\
\hline потери & 1,6 & 3,4 & 1,4 & 3,1 \\
\hline \multicolumn{5}{|l|}{ Состав жидких продуктов, \%: } \\
\hline бензол & 0,5 & 1,4 & 0,2 & 0,8 \\
\hline толуол & 0,5 & 1,4 & 0,3 & 0,9 \\
\hline этилбензол & 1,4 & 1,4 & 0,5 & 1,0 \\
\hline стирол & 0,5 & 1,4 & 0,2 & 0,9 \\
\hline бензофуран (кумарон) & 5,4 & 14,5 & & - \\
\hline фенол & 4,8 & 12,1 & 2,2 & 6,8 \\
\hline $\begin{array}{l}o \text {-крезол } \\
n \text {-крезол }\end{array}$ & 5,1 & 12,0 & $\overline{4.5}$ & $\overline{13,0}$ \\
\hline $\begin{array}{l}n \text {-крезол } \\
\text { o-этилфенол }\end{array}$ & 81,8 & 55,8 & & \\
\hline n-этилфенол & & - & 92,1 & 76,6 \\
\hline \multicolumn{5}{|l|}{ Состав газов, \%: } \\
\hline $\begin{array}{l}\mathrm{CO}_{2} \\
\mathrm{CO} \\
\mathrm{C}_{n} \mathrm{H}_{2 n}\end{array}$ & $\begin{array}{r}2,3 \\
10,4 \\
27,5 \\
23,3\end{array}$ & $\begin{array}{r}3,5 \\
18,4 \\
30,5 \\
18,7\end{array}$ & $\begin{array}{r}1,1 \\
13,2 \\
25,9 \\
19,1\end{array}$ & $\begin{array}{r}3,2 \\
21,2 \\
27,7 \\
14,9\end{array}$ \\
\hline $\mathrm{C}_{n}^{n} \mathrm{H}_{2 n+2}^{2 n}$ & 36,5 & 28,9 & 40,7 & 33,0 \\
\hline
\end{tabular}

была припаяна боковая трубка, через которую вводились исследуемые фенолы. В верхнюю часть кварцевой трубки подавалась вода, где она испарялась и нагревалась до температуры реакции. В нижней части трубки протекала реакция деструкцин. Температуру измеряли в четырех точках реактора и регистрировали самопишущим потенциометром. Продукты деструкции при выходе из реактора проходили через холодильники и электрофильтр. Жидкие продукты собирали в сборник, газы - в газометр; последний служил и регулятором давления в аппаратуре. Воду и исследуемые фенолы вводили в реактор с помощью колбовых механических дозаторов, обеспечивающих равномерную непрерывную подачу исходных веществ. Полученные в результате реакции жидкие продукты, состоявшие из воды и продуктов деструкции фенолов, экстрагировали эфиром. Затем из экстракта отгоняли эфир и раствором щелочи выделяли фенольные соединения. Полученные фенольные соединения и нейтральные компоненты анализировали отдельно на газо-жидкостном хроматографе; в качестве стационарной фазы применяли апиезон $L$ на хромосорбе. Нейтральная часть продуктов реакции хроматографировалась дополнительно, при этом стационарной фазой служил твин 80 на хромосорбе. Состав газов определяли на газоанализаторе ВТИ. Отложившийся в реакторе кокс сжигали в токе кислорода и определяли в виде $\mathrm{CO}_{2}$.

Опыты деструкции проводились при температурах $700-750^{\circ}$. Водяной пар поступал в реактор со скоростью 1,5 г/мин, а этилфенолы со скоростью 0;4 г/мин. Молярное соотношение водяного пара и фенолов было равно $25: 1$. Время контакта, вычисленное по формуле Б. Долгова $\left[{ }^{15}\right]$, составляло 5,6 сек. Опыты деструкции проводились с o- и 
Таблица 2

Выход продуктов деструкции $\alpha$ - и $n$-этилфенолов в присутствии водяного пара, в молярных процентах на прореагировавший этилфенол

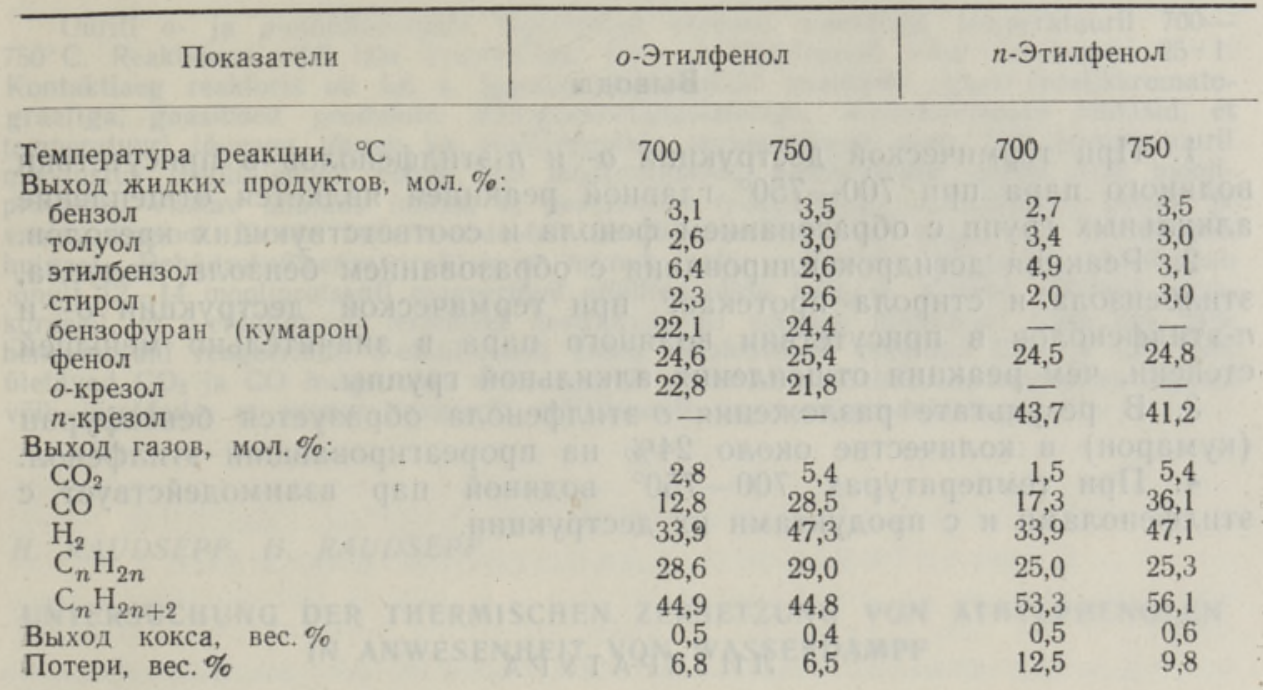

n-этилфенолом. Чистоту исходных фенолов проверяли методом газожидкостной хроматографии.

Результаты опытов приведены в табл. 1 и 2.

\section{Обсуждение результатов опытов}

Результаты опытов по разложению этилфенолов позволяют сделагь ряд новых выводов о характере процесса термической деструкции фенолов. Выяснилось, что главной реакцией при деструкции $о$ - и $n$-этилфенолов является отщепление этильной или метильной группы от молекулы этилфенола. При этом происходит образование фенола и соответствующих 0 - или $n$-крезолов. Продукты отщепления алкильных групп составляют (при $750^{\circ}$ ) в опытах с $о$-этилфенолом 47,4 мол. \% и в опытах с $n$-этилфенолом 66,0 мол. $\%$ в пересчете на прореагировавший этилфенол. Наряду с этим при деструкции о-этилфенола протекает реакция циклизации с образованием бензофурана (кумарона) в количестве примерно $24 \%$ на прореагировавший о-этилфенол. Реакция дегидроксилирования протекает в значительно меньшей степени. Общее количество углеводородов, образующихся при реакции дегидроксилирования, составляет только $12-14$ мол. \%, в пересчете на прореагировавший этилфенол (при $750^{\circ}$ ). Продукты последней реакции содержат бензол, толуол, этилбензол и стирол. Из этого можно заключить, что наряду с дегидроксилированием происходит отщепление алкильных групп и дегидрогенизация боковой цепи с образованием двойной связи. Образование стирола является вполне естественным, так как возможность протекания этой реакции объясняется электронной структурой этилфенолов. Газовые продукты деструкции содержат $\mathrm{CO}_{2}, \mathrm{CO}, \mathrm{H}_{2}$, предельные и непредельные углеводороды. Количество кислорода в образовавшихся при реакции $\mathrm{CO}_{2}$ и $\mathrm{CO}$ превышает количество кислорода, отщепляющегося.при разложении этилфенолов. Поэтому можно сделать вывод, что водяной пар в условиях деструкции фенолов взаи- 
модействует с исходными фенолами или с продуктами их разложения. Количество образовавшегося - при реакции кокса незначительное 0,4-0,6\% на прореагировавшие этилфенолы.

\section{Выводы}

1. При термической деструкции $о$ - и $n$-этилфенолов в присутствии водяного пара при $700-750^{\circ}$ главной реакцией является отщепление алкильных групп с образованием фенола и соответствующих крезолов.

2. Реакция дегидроксилирования с образованием бензола, толуола, этилбензола и стирола протекает при термической деструкции $O$ - и $n$-этилфенолов в присутствии водяного пара в значительно менышей степени, чем реакция отщепления алкильной группы.

3. В результате разложения о-этилфенола образуется бензофуран (кумарон) в количестве около $24 \%$ на прореагировавший этилфенол.

4. При температурах $700-750^{\circ}$ водяной пар взаимодействует $\mathrm{c}$ этилфенолами и с продуктами их деструкщии.

\section{ЛИ ТЕРАТ У РА}

1. Р а удсепп Х. Т., В сб.: Горючие сланцы. Химия и технология, вып. 2, АН ЭССР, Таллин, 1956, с. 107.

2. Р а удс ппп Х. Т., К арик Х. А., Тр. Таллинск. политехн. ин-та. Сер. А, № 185, $82(1961)$

3. Р а улсепп Х. Т., К арик Х. А., Тр. Таллинск. политехн. ин-та. Сер. А, № 185, $72(1961)$.

4. Р а удселп Х. Т., Қ ар ик Х. А., Тр. Таллинск. политехн. ин-та. Сер. А, № 185 , 91 (1961).

5. А арна А. Я., Мэлдер Л. И., Тр. Таллинск. политехн. ин-та. Сер. А, № 153, 59 (1958).

6. Р а удсепп Х. Т., К арик Х. А., Тр. Таллинск. политехн. ин-та. Сер. А, № 210, 53 (1964).

7. $\mathrm{H}$ a g e m a n n A., Z. angew. Chem., 42, 355, 503 (1929).

8. Cypres R., Lejeune C., Ann. mines. Belgique, 1091 (1965).

9. Given P., Chem. a. Ind., 525 (1956).

10. S chneider P. u. a. Colloq. Czech. Chem. Comm., 26, 1636 (1961).

11. Гр уздев а Н. А., Ж. прикл. хим., 25, 980 (1952).

12. Jelinek J., Chem. prủmysl, 7, 4 (1957).

13. Jones B. W., Neuw orth M. B., Ind. Engng Chem., 44, 2872 (1952).

14. Р аудсепп Х. Т., Р а удсепп Х. Э., Тр. Таллинск. политехн. ин-та. Сер. А, № 254 (1967).

15. Долгов Б. Н., Катализ в органической химии. Л., Госхимиздат, 1959, с. 47.

Таллинский политехнический институт

Поступила в редакцию 9/II 1968 


\section{H. RAUDSEPP, H. RAUDSEPP}

\section{ETUOLFENOOLIDE TERMILINE LAGUNEMINE VEEAURU MANULUSEL}

Uuriti o- ja p-etüülfenoolide lagunemist veeauru manulusel temperatuuril 700 $750^{\circ} \mathrm{C}$. Reaktsioon viidi läbi kvartstorus. Vett ja lähtefenooli vōeti vahekorras $25: 1$. Kontaktiaeg reaktoris oli $5,6 \mathrm{~s}$. Reaktsiooniproduktid analüüsiti gaasi-vedelikkromatograafiga, gaasilised produktid VTI-gaasianalüsaatoriga. Katsetulemused näitasid, et temperatuuri tōusuga tōuseb ka etüülfenoolide lagunemisaste ning $750^{\circ}$ temperatuuril moodustub o-etüülfenooli puhul 52,6 mooliprotsenti, p-etüülfenooli puhul 31,8 mooliprotsenti. Vastav analüüs näitas, et peamisteks reaktsiooniproduktideks on fenool ja vastav kresool. Nende hulk moodustab 50-60 mooliprotsenti lagunenud etüülfenooli hulgast. Dehüdroksüleerimisreaktsioon toimub palju vähemal hulgal ja moodustab ainult 12-14 mooliprotsenti reageerinud etüülfenoolide hulgast. Katsed näitasid esmakordselt, et $o$-etüülfenooli termilisel destruktsioonil veeauru manulusel tekib ligi $24 \%$ bensofuraani reageerinud o-etüülfenooli kohta. Reaktsioonil tekkinud $\mathrm{CO}_{2}$ ja $\mathrm{CO}$ hulk ületavad $\mathrm{CO}_{2}$ ja $\mathrm{CO}$ hulga, mis võiks tekkida etüülfenooli dehüdroksüleerimisel. Sellest vōib järeldada, et veeaur reageerib etüülfenooli lagunemisproduktidega.

\section{H. RAUDSEPP, H. RAUDSEPP}

\section{UNTERSUCHUNG DER THERMISCHEN ZERSETZUNG VON ATHYLPHENOLEN IN ANWESENHEIT VON WASSERDAMPF}

Es wurde die thermische Zersetzung von Athylphenolen in Anwesenheit von Wasserdampf bei $700-750^{\circ} \mathrm{C}$ untersucht. Die Reaktion wurde in einem Quarzrohr durchgeführt. Das Verhältnis des Wasserdampfes zum Athylphenol betrug 25:1. Die Dauer der Reaktionszeit war 5,6 Sek. Die flüssigen Reaktionsprodukte wurden gaschromatographisch, die gasförmigen Reaktionsprodukte mit einem VTI-Gasanalysator analysiert. Die Resultate der Untersuchung zeigten, daß die Zersetzung der Athylphenole bei der Steigerung der Reaktionstemperatur ansteigt und bei $750^{\circ} 52,6 \%$ des $o$-Athylphenols und $31,8 \%$ des $p$-Athylphenols ausmacht. Die Hauptprodukte der thermischen Zersetzung der Athylphenole sind Phenol und die entsprechenden Kresole. Ihre Summe bildet 50-60 Mole per 100 Mole der zersetzten Athylphenole. Die Dehydroxylierungsreaktion kommt in weit kleineren Mengen vor und beträgt nur ca 12-14 Mol-\% der zersetzten Athylphenole. Die Untersuchungen zeigten, daß bei thermischer Zersetzung des o-Athylphenols in Anwesenheit von Wasserdampf Bildung von Benzofuran stattfindet. Die Menge der $\mathrm{CO}_{2}$ und $\mathrm{CO}$, die sich während der Zersetzung der Âthylphenole bildet, ist weit größer als die Menge dieser Gase, die infolge der Dehydroxylierungsreaktion der Athylphenole entstehen könnte. Daraus kann man schließen, daß Wasserdampf mit den Zersetzungsprodukten der Athylphenole in Reaktion tritt. 